\title{
Pain, anxiety, and depression during bone marrow aspiration and biopsy
}

\author{
Kemik iliği aspirasyonu ve biyopsi sırasında anksiyete-depresyon ve ağrı
}

\section{Yasemin YUVALI KARACAN, ${ }^{1}$ Burçin DEMIRCIOĞLU, ${ }^{2}$ Rıdvan ALi ${ }^{2}$}

\begin{abstract}
Summary
Objectives: This study is performed with the aim of prospectively analyzing the factors that affect pain, anxiety, and depression in cases for whom bone marrow aspiration and biopsy are performed and the relationships among them.

Methods: This study consisted of 90 patients who consulted to Department of Hematology, Faculty of Medicine, Uludag University, and followed-up for bone marrow aspiration and biopsy indication. The data was gathered using a personal information form, Hospital Anxiety Depression scale, and Wong-Baker face pain scale where generally face expressions exist.

Results: The average age of the patients who participated in the study was 50.90 years (16.59), and the pain level after the application was 1.98 (1.33). After the application, a positive relationship is determined between the pain level and anxiety $(r=-0.79 ; p=0.02)$, whereas this has a negative relationship with age $(r=0.78 ; p=0.03)$.

Conclusion: As a result, pain develops depending on bone marrow aspiration and biopsy; therefore, taking precautions aimed at alleviating pain and evaluation of pain before and after the application within the scope of total maintenance have been suggested.

Keywords: Anxiety-depression; bone marrow aspiration and biopsy; pain.

\section{Özet}

Amaç: Bu çalışma kemik iliği aspirasyonu ya da biyopsisi yapılan olguların anksiyete-depresyon ve ağrısını etkileyen faktörlerle birlikte, bunlar arasındaki ilişkinin prospektif olarak incelenmesi amacıyla yapılmıştır.

Gereç ve Yöntem: Çalışmanın örneklemini Uludağ Üniversitesi Tıp Fakültesi Hematoloji Bilim Dalı’ nda takip edilen kemik iliği aspirasyonu ve biyopsi endikasyonu olup yapılmak üzere başvuran 90 hasta oluşturmuştur. Veriler kişisel bilgi formu, Hastane Anksiyete Depresyon (HAD-S) Ölçeği ve görsel olarak yüz ifadelerinin yer aldığı Wong-Baker yüz ağrı skalası kullanılarak toplanmıştır.

Bulgular: Çalışmaya katılan hastaların yaş ortalaması 50.90 (16.59), işlem sonrası ağrı şiddeti 1.98 (1.33)'dur. Kadınlarda ve biyopsi işleminde ağıı daha yüksektir. İşlem sonrası ağrı şiddeti ve anksiyete arasında pozitif yönde ( $r=0.97 ; p=0.01)$, ağrı ile depresyon $(r=-0.79 ; p=0.02)$ ve yaş $(r=-0.78, p=0.03)$ arasında negatif yönde ilişki saptanmıştır.

Sonuç: Kemik iliği aspirasyonu ve biyopsisine bağlı olarak ağrı gelişmektedir bu nedenle bütüncül bakım kapsamında ağrının işlem öncesi ve işlem sonrası değerlendirilmesi ve ağrının azaltılmasına yönelik önlemler alınması önerilmiştir.
\end{abstract}

Anahtar sözcükler: Ağrı; anksiyete ve depresyon; kemik iliği biyopsi ve aspirasyonu.

\section{Introduction}

Hematologic patients go through many processes until a diagnosis is made. The hardest and the most difficult one during this period is the diagnosis process. One of the most commonly used methods is bone marrow aspiration and biopsy (BMAB), which provides morphological, immunological, cytogenetical, and histopathological examination of the bone marrow. This application has an important position in the diagnosis of hematological diseases, in addition to the primary and secondary malign diseases. Besides, it can help with staging and sometimes diagnosis of lymphoproliferative diseases, research of fever of unknown origin, and diagnosis of disseminated fungal infections and storage diseases. ${ }^{[1]}$ BMAB was performed in the 19th century for the first time, and it is an application to be performed at the bedside by a medical specialist. ${ }^{[2]}$ BMAB is used

\footnotetext{
'Department of Oncology, Uludag University, Bursa, Turkey ${ }^{2}$ Department of Hematology, Uludag University, Bursa, Turkey

Correspondence: Hemş. Yasemin Yuvalı Karacan. Uludağ Üniversitesi, Onkoloji Bilim Dalı, Bursa, Turkey.

Phone: +90 - 532 - 7141814 e-mail: jblacksoul@yahoo.com

(C) 2017 Turkish Society of Algology
}

Submitted (Başvuru tarihi) 02.12.2016 Accepted after revision (Düzeltme sonrası kabul tarihi) 11.09.2017 Available online date (Online yayımlanma tarihi) 14.11.2017 
in the diagnosis and treatment of several hematological diseases and solid tumors; it is very painful because it is an invasive procedure. ${ }^{[3]}$ Portnow et al. have indicated that lumbar puncture, central venous catheter placing, and BMAB application in cancer patients are the most painful applications because they are performed with an incision being made on the body. Pain is a kind of unpleasant personal feeling and pattern of behavior; therefore, it leads the individual to get rid of painful stimulant. It has been indicated that in addition to anesthetics, hypnosis, cognitive behavioral therapies, and art therapy are used for children aimed at easing the pain. ${ }^{[3]}$ On the other hand, local anesthetics are generally used for adults. Despite that there have been several innovations in medicine, an overall protocol to prevent pain, which occurs during $B M A B$, does not exist and efficient methods have not been developed to prevent pain. ${ }^{[4]}$

Hematologic patients can experience anxiety and depression for the reason of uncertainty, in addition to pain, during the process of diagnosis. In this process, BMAB can increase anxiety and depression in patients. Means-Christensen et al. have indicated that anxiety and depression are increased in patients presenting with pain. ${ }^{[5]}$ Therefore, we aimed to prospectively evaluate the factors that affect anxiety, depression, and pain in cases for whom bone marrow aspiration or biopsy are performed and the relationship among them.

\section{Materials and Methods}

This study included patients who were monitored in Department of Hematology, Faculty of Medicine, Uludag University, for BMAB between 2/10/2015 and $3 / 30 / 2015$. Ninety patients met the criteria of the study (adults aged $\geq 18$, not having communication barrier or any kind of mental illness) and agreed to take part in the study. To gather the research data, personal information form, Hospital Anxiety Depression Scale (HAD-S), and Wong-Baker Faces Pain Rating Scale (WBFPS), which is used to diagnose pain level, numbered between 0 and 5 are used. Data collection tools were applied in face to face meetings.

HADS was developed by Zigmond and Snaith to determine the risk of depression and anxiety and to measure its level and severity changes ${ }^{[6]}$ The study of the validity and reliability of the scale was performed by Aydemir et al. in Turkey ${ }^{[7]}$ It is used to determine the risk group by identifying anxiety and depression, not with the aim of making a diagnosis for the patients who consult to primary care health service and have physical diseases. Half of the 14 questions, the odd numbers measured the anxiety while the even numbers measured that of depression. The answers are graded with a 4-point Likert scale between 0 and 3. The lowest point which a patient can score from the two scales is 0 and the highest point is 21 . The breakpoint of HAD-S Turkish form has been determined as 10 for the anxiety subscale (HADS-A) and 7 for depression subscale.

The systolic blood pressure (SKB), diastolic blood pressure (DKB), heart rate, and respiration of the patients were also evaluated. The blood pressures of the patients were measured by a standard mercury reference sphygmomanometer (ERKA 3000; two observers).

The interview was conducted in the waiting hall 30-60 min before BMAB. During the interview, socio-demographic characteristics and characteristics regarding the disease form, anxiety, and depression state before BMAB were evaluated. Furthermore, patients were questioned on their previous biopsy experiences.

BMAB application protocol: The most commonly used method for these applications is narcotizing the region where the local anesthetics have to be administered. Local anesthetics are weak bases; they block sodium channels and prevent the action potential from sprawling along the nerve fibers. The effect of the local anesthetic depends on several factors like the type becoming blood stained of the region where injection has been done.

The application of aspiration is removing the bone marrow with the help of an injector by entering with a special sternum or crista iliaca posterior needle, and it is mostly performed for the diagnosis of leukemia. The sample collected is put on the glass, stained with some special dyes, similar to that used in peripheral smear, and examined under the microscope. Only 5 cc of $2 \%$ priloc as the sternum anesthetic was administered to the patients during the aspiration 
and 5 min after it, the application had been done.

For the bone marrow biopsy, mostly crista iliaca posterior superior is preferred. In this study, $10 \mathrm{cc}$ of $2 \%$ priloc was administered to the patients who would undergo both biopsy and aspiration, and the application had been done 5 min later. For biopsy patients, an 8-Gc-marked Matex biopsy needle was used. After the biopsy, the removed piece of bone was placed in formaldehyde. Afterwards, a sample was taken by entering the marrow material again at a 45-degree angle. All these aforementioned procedures were performed by an educated specialist doctor were all carried out by a medical specialist. The interview was conducted 30 minutes after $B M A B$. The pain severity, anxiety, and depression state of the patients were evaluated.

Informed consent was obtained from all patients prior to study enrollment. The study was approved by the Regional Ethics Committee of Uludag University.

\section{Statistical analysis}

Statistical data was analyzed with the SPSS 20 program using percentages and correlation regression analysis. $\mathrm{P}<0.05$ was considered statistically significant.

\section{Results}

The average age of the patients in the study was 50.90 years (16.59), $71.1 \%$ of whom were male and $70 \%$ were of primary education grade. $76.7 \%$ of the patients underwent both aspiration and biopsy. The application was done in $26.7 \%$ of the patients with prediagnosed lymphoma and it was applied in $84.5 \%$ of the patients in the posterior iliac crest region. Biopsy has had not been done to $62.2 \%$ of the patients during the diagnosis and it has had not been applied to $55.6 \%$ of them before. Only $12.4 \%$ of the patients had received information from healthcare personnel (Table 1). The pain level after the application was 1.98 (1.33) and it was statistically significant $(p=0.04)$; the pain score was higher in women $(2.38 \pm 1.55)$ than in men (1.75 \pm 1.27$)$, which was not tabulated. Additionally, to evaluate the pain level in the patients after the application; it was stated that it was 2.42 (1.51) during biopsy, 1.35 (1.08) during aspiration, and 2.00 (1.40) during both biopsy and aspiration, but it is not statistically significant.
Anxiety, depression, systolic and diastolic blood pressure, and respiration values of the patients are presented in Table 2. It was stated that there is a statistically significant difference in the values after the application: there is an increase in HADS-D and decrease in SKB, DKB, heart rate, and respiration. It has been determined in the correlation analysis that there is a positive relation between the post-application pain level and anxiety $(r=0.97 ; p=0.01)$ and a negative relation between the post-application pain and depression $(r=0.79 ; p=0.02)$ and age $(r=0.78$; $\mathrm{p}=0.03$ ).

Linear regression analysis was used to determine

Table 1. Patients' characteristics

\begin{tabular}{|c|c|}
\hline Total number & $n(\%)$ \\
\hline Age (mean $\pm S D)$ & $50.90(16.59)$ \\
\hline \multicolumn{2}{|l|}{ Gender } \\
\hline Female & $64(29.9)$ \\
\hline Male & $26(71.1)$ \\
\hline \multicolumn{2}{|l|}{ Disease category } \\
\hline Acute leukemia & $14(15.6)$ \\
\hline Chronic leukemia & $5(5.6)$ \\
\hline Lymphoma & $24(26.7)$ \\
\hline Multiple myeloma & $17(18.9)$ \\
\hline Myelodysplastic syndrome & $10(11.2)$ \\
\hline Other hematologic disease & $20(22.4)$ \\
\hline \multicolumn{2}{|l|}{ Site of bone marrow aspiration } \\
\hline Posterior iliac crest & $76(84.5)$ \\
\hline Sternum & $14(15.6)$ \\
\hline \multicolumn{2}{|l|}{ Type of bone marrow aspiration } \\
\hline Aspiration & $14(15.6)$ \\
\hline Biopsy & $7(7.8)$ \\
\hline Both aspiration and biopsy & $69(76.7)$ \\
\hline \multicolumn{2}{|l|}{ Indication } \\
\hline Diagnostic/staging & $56(62.2)$ \\
\hline Remission status & $34(37.8)$ \\
\hline \multicolumn{2}{|l|}{ Previous biopsies or aspirates } \\
\hline No previous bone marrow aspiration & $50(55.6)$ \\
\hline$>1$ times & $40(44.4)$ \\
\hline \multicolumn{2}{|l|}{ Information source } \\
\hline Nurse & $7(7.8)$ \\
\hline Physician & $4(4.4)$ \\
\hline Relative & $62(68.9)$ \\
\hline Other sources & $17(18.9)$ \\
\hline
\end{tabular}


Table 2. The changes in the patients with respect to HADS-A, HADS-D and some measurements-before and after the application

\begin{tabular}{lcccc}
\hline Scales and measurements & Before the application & After the application & $\mathbf{t}^{*}$ & $\mathbf{p}^{* *}$ \\
\hline HADS-A & $0.71(0.45)$ & $11.91(3.48)$ & -34.13 & 0.00 \\
HADS-D & $0.71(0.45)$ & $8.70(2.29)$ & -38.60 & 0.00 \\
Systolic blood pressure & $129.66(23.38)$ & $120.55(24.04)$ & 4.54 & 0.00 \\
Diastolic blood pressure & $77.22(11.61)$ & $72.66(13.30)$ & 3.51 & 0.00 \\
Heart rate & $89.44(12.32)$ & $83.86(11.08)$ & 5.13 & 0.00 \\
Respiration & $20.26(2.20)$ & $19.82(2.29)$ & 2.66 & 0.00 \\
\hline
\end{tabular}

*Independent sample t test was used; ** $\mathrm{p}<0.05$; HADS-A: Hospital Anxiety Depression Scale-Anxiety; HADS-D: Hospital Anxiety Depression Scale-Depression

how the independent variables such as age, gender, marital status, educational status, indication, previous biopsies or aspirates, before and after HADS-A and HADS-D and predict the pain, the R and R2 factors were found as 0.31 and 0.99 , respectively. Moreover, it was observed that $99.0 \%$ of the total variance at the pain was explained by the above variables. However, after the linear regression analysis, it was understood that these variables were not significant predictors of pain score (Table 3 ).

\section{Discussion}

Talamo et al. ${ }^{[8]}$ had stated in their studies of 2010 and 2012 that the average pain score in a 5-point scale is 2.1 and the pain score of the patients in a 10-point scale is 3.2 (2.6), while Liden et al. ${ }^{[9]}$ stated in their study of 2009 that VAS score is $37 \mathrm{~mm}$ in a $100-\mathrm{mm}$ scale. Similarly, in our study, the pain score was below average. As it can be seen clearly in previous studies, the patients experienced pain during this application.

In this study, correlation and regression analysis was performed to understand pain and the factors affecting it. In our study, it was determined that the pain level is higher in female patients than in male patients. Also, in previous studies, it was stated that gender differences affect the pain level; these previous studies also stated that pain is more common and intense in women, but the analgesic response is less. ${ }^{[8,10-12]}$ In this study, the phase of the menstrual period, female patients experienced had not been determined, but it is known that women are more interoceptive to pain. ${ }^{[13]}$

Previous studies have shown that there is a relation
Table 3. Multiple linear regression analysis results of the independent variables with the total score of the pain for BMAB patients.

\begin{tabular}{lccccc}
\hline & \multicolumn{5}{c}{$\begin{array}{c}\text { Total score of the pain } \\
\text { for BMAB patients }\end{array}$} \\
\cline { 2 - 6 } Model & B & SH & Beta & t & p \\
\hline HAD-A & -0.04 & 0.08 & -0.01 & -0.55 & 0.58 \\
HAD-D & 0.07 & 0.10 & 0.11 & 0.66 & 0.50 \\
HADS-A (After) & 0.74 & 0.61 & 0.24 & 1.21 & 0.22 \\
HADS-D (After) & -0.50 & 0.56 & -1.65 & -089 & 0.37 \\
Age & -0.00 & 0.01 & -0.58 & -0.40 & -0.68 \\
Gender & 0.60 & 0.37 & 0.19 & 1.61 & 0.11 \\
Marital status & -0.10 & 0.53 & -0.02 & -0.19 & 0.84 \\
Education & 0.10 & 0.25 & 0.05 & 0.43 & 0.66 \\
Kind of application & 0.13 & 0.13 & 0.14 & 0.99 & 0.32 \\
How many times & -0.04 & 0.33 & -0.01 & -0.13 & 0.89 \\
it is applied & & & & & \\
Diagnosis & 0.00 & 0.13 & 0.00 & 0.02 & 0.98 \\
\hline
\end{tabular}

$R=0.3 ; R^{2}=0.99 ; F=0.78 ; p=0.67 ;$ Durbin-Watson=1.613

between pain and anxiety in medical attentions. ${ }^{[14]}$ It is worth mentioning that before the invasive procedures are applied, anxiety increases in several patients and anxiety increases heart rate, respiration, and blood pressure in patients indirectly. ${ }^{[15]}$ Surprisingly enough, it can be seen in our study that postapplication anxiety and depression score was higher, but there was a decrease in SKB, DKB, respiration, and heart rate. This situation may have occurred for a few following reasons:

i) Fear of pain before the application and uncertainty related to the disease may have increased the anxi- 
ety and indirectly increased these parameters.

ii) It is also thought that because some information about the treatment period of this application had been given and it is the beginning of the diagnosis period, anxiety and depression score in the patients may have increased.

Besides, in our study, it has been stated that pain and anxiety has a positive relation. In several previous studies, it has been determined that there is a relation between anxiety and pain. ${ }^{[16-18]}$ Moreover, Liden et al. ${ }^{[18]}$ had stated that anxiety concerning the use of needle in the application or the result of the diagnosis affects the pain.

It is stated that pain is more intense in patients who experienced BMAB before compared with the ones experiencing it for the first time. ${ }^{[14,19]}$ There is not a statistically significant difference between the pain level of patients experiencing BMAB for the first time and the ones who experienced it before in our study. Different results have been obtained concerning the relation between the pain level and age. In some studies, it is stated that there is a relation between the pain level and age. ${ }^{[9,20]}$ While in another one, the statement is on the contrary. ${ }^{[19]}$ In the correlation analysis of our study, a negative relation between pain level and age has been determined, but it was also seen that age is not a significant precursor for pain score.

One of the important limitations of our study is that the chronic pain of the patients and the pain level of post-application had not been considered. However, the chronic pain, pain experience, and the beliefs about the pain of the patient can affect it during the period of BMAB. Liden et al. ${ }^{[18]}$ have stated that there is a relation between the pain during the application and previous experience of the patient who had experienced $\mathrm{BMAB} \cdot{ }^{[14]}$

It is known that giving written or oral information to the patients is a factor to decrease pain and anxiety. Specifically, this can be achieved more easily in elective situations like BMAB. It is understood in this study that all the patients have kept informed and most of them have got the information from the sources except for the healthcare professionals.
Patients' finding this information sufficient have not been questioned.

As a result, pain is an important problem in $B M A B$ patients and pain assessment in pain management is an important cornerstone because of the fact that pain is a multidimensional experience. Identifying the pain level and severity by pain measurement is significant for planning and evaluating care for it. Because of the fact that pain is a subjective finding, the most valid method is questioning the pain experience of the patient. On the other hand, as Liden et al. ${ }^{[18]}$ had stated in their study, patients and healthcare personnel can have different perspectives about the pain during BMAB. This situation can also harden the pain management.

Considering that the sensual, cognitive, and behavioral aspects of pain are required in addition to the perceptual way. Pain can sometimes be a symptom of a psychiatric disorder, but it can also be a physical behavior example of the sensory world. In order to decrease the pain level of the invasive application, the patient should be evaluated well. In this study, it has come to light that giving information to the patient before the application affects the collaboration between the team and the patient for perception of pain and relieving it.

Local analgesics and generally lidocaine-like drugs are used to reduce BMAB pain. Chloroprocaine or bupivacaine hydrochloride may be used in cases of side effects associated with lidocaine use. Lorazepam, midazolam, or diazepam may be administered via IV route in addition to local anesthesia. In recent studies nitrous oxide/oxygen $\left(\mathrm{N}_{2} \mathrm{O} / \mathrm{O}_{2}\right)$ or nitrous oxide can be applied alone. ${ }^{[2]}$

$B M A B$ is a commonly used method that is applied in hematologic patients and it is important in the diagnosis and monitoring the siege of the disease and efficiency of the treatment. For this reason, alleviating the pain before and after the application is significant in terms of ensuring a good care and decreasing the anxiety. Also, because of the fact that there is not any study like this in literature, it is thought that this study and its results are important. After all, this study was carried out in one center, which remains a drawback of this study.

It is obvious from this study that anxiety and depres- 
sion increase after the application. It can be related to the pain that the patient experiences during the application. For this reason, evaluating the pain level before the application, relieving the pain during the application, giving information to the patient before the application, and some attempts to relieve the pain according to the age and gender have been suggested.

\section{Conflict-of-interest issues regarding the authorship or article: None declared.}

\section{Peer-rewiew: Externally peer-reviewed.}

\section{References}

1. Tüzüner N. Tissue biopsy in the diagnosis of hematologic malignancies. IÜ Cerrahpaşa Tıp Fak. Sürekli Tıp Eğitimi Etk 2005:51-4.

2. Hjortholm N, Jaddini E, Hałaburda K, Snarski E. Strategies of pain reduction during the bone marrow biopsy. Ann Hematol 2013;92(2):145-9.

3. Vanhelleputte P, Nijs K, Delforge M, Evers G, Vanderschueren $S$. Pain during bone marrow aspiration: prevalence and prevention. J Pain Symptom Manage 2003;26(3):860-6.

4. Talamo G, Liao J, Bayerl MG, Claxton DF, Zangari M. Oral administration of analgesia and anxiolysis for pain associated with bone marrow biopsy. Support Care Cancer 2010;18(3):301-5.

5. Means-Christensen AJ, Roy-Byrne PP, Sherbourne CD, Craske MG, Stein MB. Relationships among pain, anxiety, and depression in primary care. Depress Anxiety 2008;25(7):593-600.

6. Zigmond AS, Snaith RP. The hospital anxiety and depression scale. Acta Psychiatr Scand 1983;67(6):361-70.

7. Aydemir Ö, Güvenir T, Küey L, Kültür S. Hastane Anksiyete ve Depresyon Ölçeği Türkçe Formunun Geçerlik Güvenilirlik Çalışması. Turk Psikiyatri Derg 1997;8:280-7.

8. Talamo G, Liao J, Joudeh J, Lamparella NE, Dinh H, Malysz J, et al. Perceived levels of pain associated with bone marrow aspirates and biopsies. J Support Oncol 2012;10(4):166-70.

9. Lidén Y, Landgren O, Arnér S, Sjölund KF, Johansson E. Proce- dure-related pain among adult patients with hematologic malignancies. Acta Anaesthesiol Scand 2009;53(3):354-63.

10. Wranker LS, Rennemark M, Berglund J. Pain among older adults from a gender perspective: findings from the Swedish National Study on Aging and Care (SNAC-Blekinge). Scand J Public Health 2016;44(3):258-63.

11. Shega JW, Tiedt AD, Grant K, Dale W. Pain measurement in the National Social Life, Health, and Aging Project: presence, intensity, and location. J Gerontol B Psychol Sci Soc Sci 2014;69 Suppl 2:S191-7.

12. Kano M, Farmer AD, Aziz Q, Giampietro VP, Brammer MJ, Williams SC, et al. Sex differences in brain response to anticipated and experienced visceral pain in healthy subjects. Am J Physiol Gastrointest Liver Physiol 2013;304(8):G687-99.

13. Fillingim RB, King $C D$, Ribeiro-Dasilva $M C$, Rahim-Williams B, Riley JL 3rd. Sex, gender, and pain: a review of recent clinical and experimental findings. J Pain 2009;10(5):447-85.

14. Kuivalainen AM, Pitkäniemi J, Widenius T, Elonen E, Rosenberg P. Anxiety and pain during bone marrow aspiration and biopsy. Scand J Pain 2012;3:92-6.

15. Roberts N, Czajkowska Z, Radiotis G, Körner A. Distress and coping strategies among patients with skin cancer. J Clin Psychol Med Settings 2013;20(2):209-14.

16. Ozalp G, Sarioglu R, Tuncel G, Aslan K, Kadiogullari N. Preoperative emotional states in patients with breast cancer and postoperative pain. Acta Anaesthesiol Scand 2003;47(1):26-9.

17. Keogh E, Barlow C, Mounce C, Bond FW. Assessing the relationship between cold pressor pain responses and dimensions of the anxiety sensitivity profile in healthy men and women. Cogn Behav Ther 2006;35(4):198-206.

18. Lidén $Y$, Olofsson N, Landgren O, Johansson E. Pain and anxiety during bone marrow aspiration/biopsy: Comparison of ratings among patients versus health-care professionals. Eur J Oncol Nurs 2012;16(3):323-9.

19. Degen C, Christen S, Rovo A, Gratwohl A. Bone marrow examination: a prospective survey on factors associated with pain. Ann Hematol 2010;89(6):619-24.

20. Vanhelleputte P, Nijs K, Delforge M, Evers G, Vanderschueren S. Pain during bone marrow aspiration: prevalence and prevention. J Pain Symptom Manage 2003;26(3):860-6. 
the bedside by a medical specialist. ${ }^{[2]}$ BMAB is used in the diagnosis and treatment of several hematological diseases and solid tumors; it is very painful because it is an invasive procedure. ${ }^{[3]}$ Portnow et al. have indicated that lumbar puncture, central venous catheter placing, and BMAB application in cancer patients are the most painful applications because they are performed with an incision being made on the body. Pain is a kind of unpleasant personal feeling and pattern of behavior; therefore, it leads the individual to get rid of painful stimulant. It has been indicated that in addition to anesthetics, hypnosis, cognitive behavioral therapies, and art therapy are used for children aimed at easing the pain..$^{[3]}$ On the other hand, local anesthetics are generally used for adults. Despite that there have been several innovations in medicine, an overall protocol to prevent pain, which occurs during $B M A B$, does not exist and efficient methods have not been developed to prevent pain. ${ }^{[4]}$

Hematologic patients can experience anxiety and depression for the reason of uncertainty, in addition to pain, during the process of diagnosis. In this process, BMAB can increase anxiety and depression in patients. Means-Christensen et al. have indicated that anxiety and depression are increased in patients presenting with pain. ${ }^{[5]}$ Therefore, we aimed to prospectively evaluate the factors that affect anxiety, depression, and pain in cases for whom bone marrow aspiration or biopsy are performed and the relationship among them.

\section{Materials and Methods}

This study included patients who were monitored in Department of Hematology, Faculty of Medicine, Uludag University, for BMAB between 2/10/2015 and $3 / 30 / 2015$. Ninety patients met the criteria of the study (adults aged $\geq 18$, not having communication barrier or any kind of mental illness) and agreed to take part in the study. To gather the research data, personal information form, Hospital Anxiety Depression Scale (HAD-S), and Wong-Baker Faces Pain Rating Scale (WBFPS), which is used to diagnose pain level, numbered between 0 and 5 are used. Data collection tools were applied in face to face meetings.

HADS was developed by Zigmond and Snaith to determine the risk of depression and anxiety and to measure its level and severity changes. ${ }^{[6]}$ The study of the validity and reliability of the scale was performed by Aydemir et al. in Turkey ${ }^{[7]}$ It is used to determine the risk group by identifying anxiety and depression, not with the aim of making a diagnosis for the patients who consult to primary care health service and have physical diseases. Half of the 14 questions, the odd numbers measured the anxiety while the even numbers measured that of depression. The answers are graded with a 4-point Likert scale between 0 and 3. The lowest point which a patient can score from the two scales is 0 and the highest point is 21. The breakpoint of HAD-S Turkish form has been determined as 10 for the anxiety subscale (HADS-A) and 7 for depression subscale.

The systolic blood pressure (SKB), diastolic blood pressure (DKB), heart rate, and respiration of the patients were also evaluated. The blood pressures of the patients were measured by a standard mercury reference sphygmomanometer (ERKA 3000; two observers).

The interview was conducted in the waiting hall 30-60 min before BMAB. During the interview, socio-demographic characteristics and characteristics regarding the disease form, anxiety, and depression state before BMAB were evaluated. Furthermore, patients were questioned on their previous biopsy experiences.

BMAB application protocol: The most commonly used method for these applications is narcotizing the region where the local anesthetics have to be administered. Local anesthetics are weak bases; they block sodium channels and prevent the action potential from sprawling along the nerve fibers. The effect of the local anesthetic depends on several factors like the type becoming blood stained of the region where injection has been done.

The application of aspiration is removing the bone marrow with the help of an injector by entering with a special sternum or crista iliaca posterior needle, and it is mostly performed for the diagnosis of leukemia. The sample collected is put on the glass, stained with some special dyes, similar to that used in peripheral smear, and examined under the microscope. Only 5 cc of $2 \%$ priloc as the sternum anesthetic was 
administered to the patients during the aspiration and $5 \mathrm{~min}$ after it, the application had been done.

For the bone marrow biopsy, mostly crista iliaca posterior superior is preferred. In this study, $10 \mathrm{cc}$ of $2 \%$ priloc was administered to the patients who would undergo both biopsy and aspiration, and the application had been done 5 min later. For biopsy patients, an 8-Gc-marked Matex biopsy needle was used. After the biopsy, the removed piece of bone was placed in formaldehyde. Afterwards, a sample was taken by entering the marrow material again at a 45-degree angle. All these aforementioned procedures were performed by an educated specialist doctor were all carried out by a medical specialist. The interview was conducted 30 minutes after $B M A B$. The pain severity, anxiety, and depression state of the patients were evaluated.

Informed consent was obtained from all patients prior to study enrollment. The study was approved by the Regional Ethics Committee of Uludag University.

\section{Statistical analysis}

Statistical data was analyzed with the SPSS 20 program using percentages and correlation regression analysis. $\mathrm{P}<0.05$ was considered statistically significant.

\section{Results}

The average age of the patients in the study was 50.90 years (16.59), $71.1 \%$ of whom were male and $70 \%$ were of primary education grade. $76.7 \%$ of the patients underwent both aspiration and biopsy. The application was done in $26.7 \%$ of the patients with prediagnosed lymphoma and it was applied in $84.5 \%$ of the patients in the posterior iliac crest region. $\mathrm{Bi}$ opsy has had not been done to $62.2 \%$ of the patients during the diagnosis and it has had not been applied to $55.6 \%$ of them before. Only $12.4 \%$ of the patients had received information from healthcare personnel (Table 1). The pain level after the application was 1.98 (1.33) and it was statistically significant $(p=0.04)$; the pain score was higher in women $(2.38 \pm 1.55)$ than in men (1.75 \pm 1.27$)$, which was not tabulated. Additionally, to evaluate the pain level in the patients after the application; it was stated that it was 2.42 (1.51) during biopsy, 1.35 (1.08) during aspiration, and 2.00 (1.40) during both biopsy and aspiration, but it is not statistically significant.

Anxiety, depression, systolic and diastolic blood pressure, and respiration values of the patients are presented in Table 2. It was stated that there is a statistically significant difference in the values after the application: there is an increase in HADS-D and decrease in SKB, DKB, heart rate, and respiration. It has been determined in the correlation analysis that there is a positive relation between the post-application pain level and anxiety $(r=0.97 ; p=0.01)$ and $a$ negative relation between the post-application pain and depression $(r=0.79 ; p=0.02)$ and age $(r=0.78$; $p=0.03$ ).

Table 1. Patients' characteristics

\begin{tabular}{|c|c|}
\hline Total number & n (\%) \\
\hline Age (mean $\pm S D)$ & $50.90(16.59)$ \\
\hline \multicolumn{2}{|l|}{ Gender } \\
\hline Female & $64(29.9)$ \\
\hline Male & $26(71.1)$ \\
\hline \multicolumn{2}{|l|}{ Disease category } \\
\hline Acute leukemia & $14(15.6)$ \\
\hline Chronic leukemia & $5(5.6)$ \\
\hline Lymphoma & $24(26.7)$ \\
\hline Multiple myeloma & $17(18.9)$ \\
\hline Myelodysplastic syndrome & $10(11.2)$ \\
\hline Other hematologic disease & $20(22.4)$ \\
\hline \multicolumn{2}{|l|}{ Site of bone marrow aspiration } \\
\hline Posterior iliac crest & $76(84.5)$ \\
\hline Sternum & $14(15.6)$ \\
\hline \multicolumn{2}{|l|}{ Type of bone marrow aspiration } \\
\hline Aspiration & $14(15.6)$ \\
\hline Biopsy & $7(7.8)$ \\
\hline Both aspiration and biopsy & $69(76.7)$ \\
\hline \multicolumn{2}{|l|}{ Indication } \\
\hline Diagnostic/staging & $56(62.2)$ \\
\hline Remission status & $34(37.8)$ \\
\hline \multicolumn{2}{|l|}{ Previous biopsies or aspirates } \\
\hline No previous bone marrow aspiration & $50(55.6)$ \\
\hline$>1$ times & $40(44.4)$ \\
\hline \multicolumn{2}{|l|}{ Information source } \\
\hline Nurse & $7(7.8)$ \\
\hline Physician & $4(4.4)$ \\
\hline Relative & $62(68.9)$ \\
\hline Other sources & 17 (18.9) \\
\hline
\end{tabular}


Table 2. The changes in the patients with respect to HADS-A, HADS-D and some measurements-before and after the application

\begin{tabular}{lcccc}
\hline Scales and measurements & Before the application & After the application & $\mathbf{t}^{*}$ & $\mathbf{p}^{* *}$ \\
\hline HADS-A & $0.71(0.45)$ & $11.91(3.48)$ & -34.13 & 0.00 \\
HADS-D & $0.71(0.45)$ & $8.70(2.29)$ & -38.60 & 0.00 \\
Systolic blood pressure & $129.66(23.38)$ & $120.55(24.04)$ & 4.54 & 0.00 \\
Diastolic blood pressure & $77.22(11.61)$ & $72.66(13.30)$ & 3.51 & 0.00 \\
Heart rate & $89.44(12.32)$ & $83.86(11.08)$ & 5.13 & 0.00 \\
Respiration & $20.26(2.20)$ & $19.82(2.29)$ & 2.66 & 0.00 \\
\hline
\end{tabular}

*Independent sample t test was used; ** $\mathrm{p}<0.05$; HADS-A: Hospital Anxiety Depression Scale-Anxiety; HADS-D: Hospital Anxiety Depression Scale-Depression

Linear regression analysis was used to determine how the independent variables such as age, gender, marital status, educational status, indication, previous biopsies or aspirates, before and after HADS-A and HADS-D and predict the pain, the R and R2 factors were found as 0.31 and 0.99 , respectively. Moreover, it was observed that $99.0 \%$ of the total variance at the pain was explained by the above variables. However, after the linear regression analysis, it was understood that these variables were not significant predictors of pain score (Table 3 ).

\section{Discussion}

Talamo et al. ${ }^{[8]}$ had stated in their studies of 2010 and 2012 that the average pain score in a 5-point scale is 2.1 and the pain score of the patients in a 10-point scale is 3.2 (2.6), while Liden et al. ${ }^{[9]}$ stated in their study of 2009 that VAS score is $37 \mathrm{~mm}$ in a $100-\mathrm{mm}$ scale. Similarly, in our study, the pain score was below average. As it can be seen clearly in previous studies, the patients experienced pain during this application.

In this study, correlation and regression analysis was performed to understand pain and the factors affecting it. In our study, it was determined that the pain level is higher in female patients than in male patients. Also, in previous studies, it was stated that gender differences affect the pain level; these previous studies also stated that pain is more common and intense in women, but the analgesic response is less. ${ }^{[8,10-12]}$ In this study, the phase of the menstrual period, female patients experienced had not been determined, but it is known that women are more interoceptive to pain. ${ }^{[13]}$
Table 3. Multiple linear regression analysis results of the independent variables with the total score of the pain for BMAB patients.

\begin{tabular}{lccccc}
\hline & \multicolumn{5}{c}{$\begin{array}{c}\text { Total score of the pain } \\
\text { for BMAB patients }\end{array}$} \\
\cline { 2 - 6 } Model & B & SH & Beta & t & p \\
\hline HAD-A & -0.04 & 0.08 & -0.01 & -0.55 & 0.58 \\
HAD-D & 0.07 & 0.10 & 0.11 & 0.66 & 0.50 \\
HADS-A (After) & 0.74 & 0.61 & 0.24 & 1.21 & 0.22 \\
HADS-D (After) & -0.50 & 0.56 & -1.65 & -089 & 0.37 \\
Age & -0.00 & 0.01 & -0.58 & -0.40 & -0.68 \\
Gender & 0.60 & 0.37 & 0.19 & 1.61 & 0.11 \\
Marital status & -0.10 & 0.53 & -0.02 & -0.19 & 0.84 \\
Education & 0.10 & 0.25 & 0.05 & 0.43 & 0.66 \\
Kind of application & 0.13 & 0.13 & 0.14 & 0.99 & 0.32 \\
How many times & -0.04 & 0.33 & -0.01 & -0.13 & 0.89 \\
it is applied & & & & & \\
Diagnosis & 0.00 & 0.13 & 0.00 & 0.02 & 0.98 \\
\hline
\end{tabular}

$R=0.3 ; R^{2}=0.99 ; F=0.78 ; p=0.67 ;$ Durbin-Watson=1.613

Previous studies have shown that there is a relation between pain and anxiety in medical attentions. ${ }^{[14]}$ It is worth mentioning that before the invasive procedures are applied, anxiety increases in several patients and anxiety increases heart rate, respiration, and blood pressure in patients indirectly. ${ }^{[15]}$ Surprisingly enough, it can be seen in our study that postapplication anxiety and depression score was higher, but there was a decrease in SKB, DKB, respiration, and heart rate. This situation may have occurred for a few following reasons:

i) Fear of pain before the application and uncertainty 
related to the disease may have increased the anxiety and indirectly increased these parameters.

ii) It is also thought that because some information about the treatment period of this application had been given and it is the beginning of the diagnosis period, anxiety and depression score in the patients may have increased.

Besides, in our study, it has been stated that pain and anxiety has a positive relation. In several previous studies, it has been determined that there is a relation between anxiety and pain. ${ }^{[16-18]}$ Moreover, Liden et al. ${ }^{[18]}$ had stated that anxiety concerning the use of needle in the application or the result of the diagnosis affects the pain.

It is stated that pain is more intense in patients who experienced BMAB before compared with the ones experiencing it for the first time. ${ }^{[14,19]}$ There is not a statistically significant difference between the pain level of patients experiencing BMAB for the first time and the ones who experienced it before in our study. Different results have been obtained concerning the relation between the pain level and age. In some studies, it is stated that there is a relation between the pain level and age. ${ }^{[9,20]}$ While in another one, the statement is on the contrary. ${ }^{[19]}$ In the correlation analysis of our study, a negative relation between pain level and age has been determined, but it was also seen that age is not a significant precursor for pain score.

One of the important limitations of our study is that the chronic pain of the patients and the pain level of post-application had not been considered. However, the chronic pain, pain experience, and the beliefs about the pain of the patient can affect it during the period of BMAB. Liden et al. ${ }^{[18]}$ have stated that there is a relation between the pain during the application and previous experience of the patient who had experienced $B M A B{ }^{[14]}$

It is known that giving written or oral information to the patients is a factor to decrease pain and anxiety. Specifically, this can be achieved more easily in elective situations like BMAB. It is understood in this study that all the patients have kept informed and most of them have got the information from the sources except for the healthcare professionals. Patients' finding this information sufficient have not been questioned.

As a result, pain is an important problem in $B M A B$ patients and pain assessment in pain management is an important cornerstone because of the fact that pain is a multidimensional experience. Identifying the pain level and severity by pain measurement is significant for planning and evaluating care for it. Because of the fact that pain is a subjective finding, the most valid method is questioning the pain experience of the patient. On the other hand, as Liden et al. ${ }^{[18]}$ had stated in their study, patients and healthcare personnel can have different perspectives about the pain during $B M A B$. This situation can also harden the pain management.

Considering that the sensual, cognitive, and behavioral aspects of pain are required in addition to the perceptual way. Pain can sometimes be a symptom of a psychiatric disorder, but it can also be a physical behavior example of the sensory world. In order to decrease the pain level of the invasive application, the patient should be evaluated well. In this study, it has come to light that giving information to the patient before the application affects the collaboration between the team and the patient for perception of pain and relieving it.

Local analgesics and generally lidocaine-like drugs are used to reduce BMAB pain. Chloroprocaine or bupivacaine hydrochloride may be used in cases of side effects associated with lidocaine use. Lorazepam, midazolam, or diazepam may be administered via IV route in addition to local anesthesia. In recent studies nitrous oxide/oxygen $\left(\mathrm{N}_{2} \mathrm{O} / \mathrm{O}_{2}\right)$ or nitrous oxide can be applied alone. ${ }^{[2]}$

BMAB is a commonly used method that is applied in hematologic patients and it is important in the diagnosis and monitoring the siege of the disease and efficiency of the treatment. For this reason, alleviating the pain before and after the application is significant in terms of ensuring a good care and decreasing the anxiety. Also, because of the fact that there is not any study like this in literature, it is thought that this study and its results are important. After all, this study was carried out in one center, which remains a drawback of this study. 
It is obvious from this study that anxiety and depression increase after the application. It can be related to the pain that the patient experiences during the application. For this reason, evaluating the pain level before the application, relieving the pain during the application, giving information to the patient before the application, and some attempts to relieve the pain according to the age and gender have been suggested.

\section{Conflict-of-interest issues regarding the authorship or article: None declared.}

\section{Peer-rewiew: Externally peer-reviewed.}

\section{References}

1. Tüzüner N. Tissue biopsy in the diagnosis of hematologic malignancies. IÜ Cerrahpaşa Tıp Fak. Sürekli Tıp Eğitimi Etk 2005:51-4.

2. Hjortholm N, Jaddini E, Hałaburda K, Snarski E. Strategies of pain reduction during the bone marrow biopsy. Ann Hematol 2013;92(2):145-9. [CrossRef]

3. Vanhelleputte P, Nijs K, Delforge M, Evers G, Vanderschueren $S$. Pain during bone marrow aspiration: prevalence and prevention. J Pain Symptom Manage 2003;26(3):860-6.

4. Talamo G, Liao J, Bayerl MG, Claxton DF, Zangari M. Oral administration of analgesia and anxiolysis for pain associated with bone marrow biopsy. Support Care Cancer 2010;18(3):301-5. [CrossRef]

5. Means-Christensen AJ, Roy-Byrne PP, Sherbourne CD, Craske MG, Stein MB. Relationships among pain, anxiety, and depression in primary care. Depress Anxiety 2008;25(7):593-600. [CrossRef]

6. Zigmond AS, Snaith RP. The hospital anxiety and depression scale. Acta Psychiatr Scand 1983;67(6):361-70. [CrossRef]

7. Aydemir Ö, Güvenir T, Küey L, Kültür S. Hastane Anksiyete ve Depresyon Ölçeği Türkçe Formunun Geçerlik Güvenilirlik Çalışması. Turk Psikiyatri Derg 1997;8:280-7.

8. Talamo G, Liao J, Joudeh J, Lamparella NE, Dinh H, Malysz J, et al. Perceived levels of pain associated with bone marrow aspirates and biopsies. J Support Oncol 2012;10(4):166-70.
9. Lidén Y, Landgren O, Arnér S, Sjölund KF, Johansson E. Procedure-related pain among adult patients with hematologic malignancies. Acta Anaesthesiol Scand 2009;53(3):354-63.

10. Wranker LS, Rennemark M, Berglund J. Pain among older adults from a gender perspective: findings from the Swedish National Study on Aging and Care (SNAC-Blekinge). Scand J Public Health 2016;44(3):258-63. [CrossRef]

11. Shega JW, Tiedt AD, Grant K, Dale W. Pain measurement in the National Social Life, Health, and Aging Project: presence, intensity, and location. J Gerontol B Psychol Sci Soc Sci 2014;69 Suppl 2:S191-7. [CrossRef]

12. Kano M, Farmer AD, Aziz Q, Giampietro VP, Brammer MJ, Williams SC, et al. Sex differences in brain response to anticipated and experienced visceral pain in healthy subjects. Am J Physiol Gastrointest Liver Physiol 2013;304(8):G687-99.

13. Fillingim $R B$, King $C D$, Ribeiro-Dasilva $M C$, Rahim-Williams B, Riley JL 3rd. Sex, gender, and pain: a review of recent clinical and experimental findings. J Pain 2009;10(5):447-85.

14. Kuivalainen AM, Pitkäniemi J, Widenius T, Elonen E, Rosenberg $P$. Anxiety and pain during bone marrow aspiration and biopsy. Scand J Pain 2012;3:92-6. [CrossRef]

15. Roberts N, Czajkowska Z, Radiotis G, Körner A. Distress and coping strategies among patients with skin cancer. J Clin Psychol Med Settings 2013;20(2):209-14. [CrossRef]

16. Ozalp G, Sarioglu R, Tuncel G, Aslan K, Kadiogullari N. Preoperative emotional states in patients with breast cancer and postoperative pain. Acta Anaesthesiol Scand 2003;47(1):26-9. [CrossRef]

17. Keogh E, Barlow C, Mounce C, Bond FW. Assessing the relationship between cold pressor pain responses and dimensions of the anxiety sensitivity profile in healthy men and women. Cogn Behav Ther 2006;35(4):198-206. [CrossRef]

18. Lidén $Y$, Olofsson N, Landgren O, Johansson E. Pain and anxiety during bone marrow aspiration/biopsy: Comparison of ratings among patients versus health-care professionals. Eur J Oncol Nurs 2012;16(3):323-9. [CrossRef]

19. Degen C, Christen S, Rovo A, Gratwohl A. Bone marrow examination: a prospective survey on factors associated with pain. Ann Hematol 2010;89(6):619-24. [CrossRef]

20. Vanhelleputte P, Nijs K, Delforge M, Evers G, Vanderschueren $S$. Pain during bone marrow aspiration: prevalence and prevention. J Pain Symptom Manage 2003;26(3):860-6. 